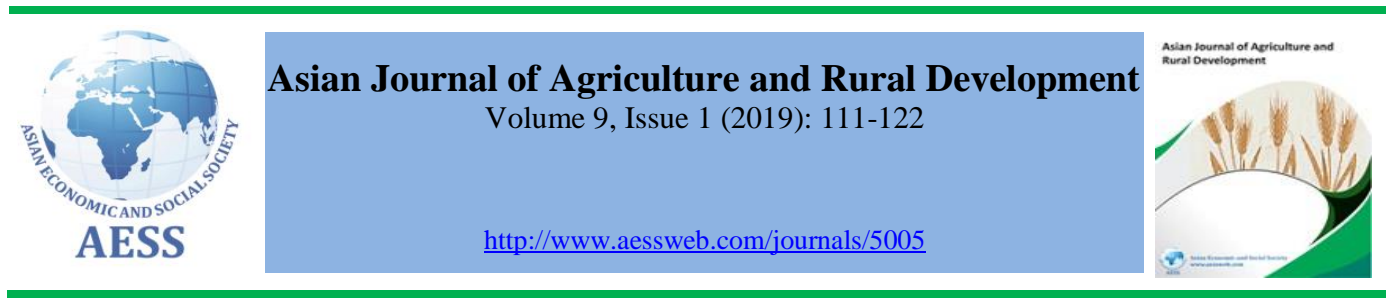

\title{
ESTABLISHMENT OF INCLUSIVE BUSINESS ON COFFEE PRODUCTION IN BALI PROVINCE: LESSON FROM THE COFFEE DEVELOPMENT PROJECT IN NUSA TENGGARA TIMUR PROVINCE, INDONESIA
}

\author{
iD Gede Sedana ${ }^{a}$, a Faculty of Agriculture, Dwijendra University, Bali,
Nengah Dasi
Astawa $^{\text {b }}$
${ }^{\mathrm{b}}$ Faculty of Economics, Undiknas University, Bali, Indonesia

\section{Indonesia}

\section{\gedesedana@gmail.com (Corresponding author)}

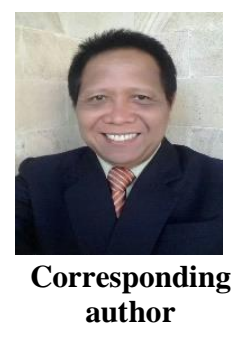

\section{ARTICLE HISTORY: \\ Received: 20-Mar-2019 \\ Accepted: 15-May-2019 \\ Online Available: 02-Jun- 2019}

\section{Keywords:}

Inclusive,

Business,

Incentives,

Sustainability

\begin{abstract}
Indonesia is one of the biggest coffee producers in the world. However, farmers' incomes are still relatively small due to low productivity, poor quality, and low price, as well as limited access to information, technology, and market. This study aims to describe the effect of inclusive business on coffee development in Bali, based on the Flores experience. The results of the study pointed out that the experience of inclusive business on coffee development in Nusa Tenggara Timur Province might also be implemented in Bali. The business model established should include the coffee farmers/farmers' cooperative, coffee buyer/exporter, bank, government, research institution, and independent actors. Among the market actors, they should have mutualism partnership in order to obtain economic incentives. This could ensure the sustainability of inclusive business on coffee development.
\end{abstract}

\begin{abstract}
Contribution/ Originality
This research is very important to develop coffee inclusive business which involves the entire stakeholders as market actors, especially to improve the welfare of coffee farmers. This research also gives contribution to make more effective and efficient partnership among the market actors, not only in the coffee production, but this might be suggested to other production, such as cocoa.
\end{abstract}

DOI: 10.18488/journal.1005/2019.9.1/1005.1.111.122

ISSN (P): 2304-1455/ISSN (E):2224-4433

How to cite: Gede Sedana and Nengah Dasi Astawa (2019). Establishment of inclusive business on coffee production in Bali province: lesson from the coffee development project in Nusa Tenggara Timur province, Indonesia. Asian Journal of Agriculture and Rural Development, 9(1), 111-122.

(C) 2019 Asian Economic and Social Society. All rights reserved. 


\section{INTRODUCTION}

Coffee is one of the tropical commodities that can be traded globally. This commodity presently has an increasing tendency in the domestic and international markets. Comparing to other commodities, coffee seemingly has the uniqueness in the relation to the specific taste, which is strongly dependent on the location of the plantation (Supriadi and Pranowo, 2015; Ayelign and Sabally, 2013). In Indonesia, it has been found that various specialty coffees are produced by farmers within different regions (provinces), such as Bali Kintamani Coffee, Flores Bajawa Coffee, Gayo Coffee, Toraja Coffee, and others. (Belachew et al., 2015; Sedana and Astawa, 2016; Fadhil et al. 2018). Aknesia et al. (2015) mentioned that the specific taste of each coffee is also strongly influenced by the harvesting and processing techniques at the farmer level.

At least, there are 50 countries in the world which have produced coffee, including Indonesia. There are two main varieties of coffee (Arabica and Robusta) which are being planted in the world. In 2016, for example, Arabica coffee production was significantly higher produced (around 102 million bags), compared to Robusta coffee which was about 56 million bags ( 1 bag equals to $60 \mathrm{~kg}$ ). The largest coffee producing country is Brazil with 55 million bags produced in 2016, followed by other countries such as Colombia (14.5 million bags), Indonesia (11.2 million bags). However, coffee production by Indonesia is still relatively small at around $8 \%$ of world coffee production, amounting to 637,000 tons in 2017. Coffee produced by farmers in Indonesia has been exported to several countries in the world, such as the United States, Germany, Malaysia, Italy, Japan, Russia, Egypt, Britain, Belgium and Canada (Figure 1). The development of coffee production in Indonesia from 2006 to 2017 can be seen in Table 1.

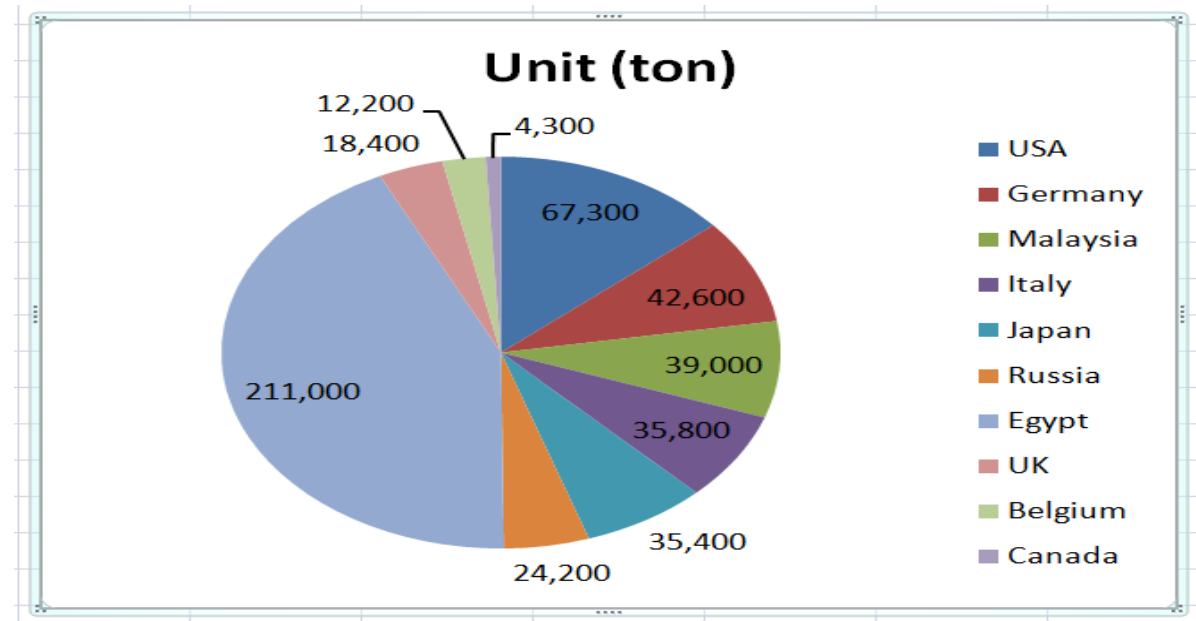

\section{Figure 1: Quantity of exported coffee to the world}

Coffee management within many countries has various aspects of interests, such as social aspects, cultures other than economics and the environment both in rural and cross-village areas, and even nationally and internationally (Kilian et al., 2006). In developing countries including Indonesia, coffee cultivation is one of the main sources of income for smallholder farmers, who manage on less than one hectare of land (Mutandwa et al., 2009). Both important types of coffee are also cultivated in Indonesia which is in line with the altitude of the land. If the areas have an altitude of less than 1,000 m above sea level, Robusta Coffee trees are cultivated. Meanwhile, in areas with altitudes exceeding 1,000 m above sea level, Arabica Coffee trees are suitable for planting. In general, the area of management of Arabica Coffee plants is still much lower compared to the Robusta Coffee plants. 
Table 1: Coffee production in Indonesia

\begin{tabular}{lcc}
\hline No & Year & $\begin{array}{c}\text { Production } \\
\text { (x 000 ton) }\end{array}$ \\
\hline 1 & 2006 & 682.16 \\
2 & 2007 & 676.48 \\
3 & 2008 & 698.02 \\
4 & 2009 & 682.69 \\
5 & 2010 & 686.92 \\
6 & 2011 & 638.65 \\
7 & 2012 & 691.16 \\
8 & 2013 & 675.88 \\
9 & 2014 & 643.86 \\
10 & 2015 & 639.31 \\
11 & 2016 & 637.54 \\
\hline
\end{tabular}

Source: Report on coffee production statistics (Ministry of Agriculture 2016/2017)

The management of coffee farming in Indonesia has still generated a relative small income at the farmer level. Several reasons of this condition are the low productivity, poor quality of product, low price, limited access to information, technology and market (Dowdall, 2012; Gathura, 2013; Minh et al., 2016; Mapiemfu-Lamaré et al., 2017). Aside from these, smallholder farmers have no appropriate partnership with the business actor, such as buyers, exporters, and others. A case of inclusive business on coffee development in the East Manggarai, Nusa Tenggara Timur Province (Indonesia) has shown the successful achievement of the project (Australia-Indonesia PartnershipPromoting Rural Income through Support for Markets in Agriculture, called AIP-PRISMA) to increase productivity and income of farmers (Sedana and Astawa, 2016). This area is one of the coffee production centers in Indonesia. In this project, coffee farmers, through their organization (cooperative) could have good partnership with the market actors under the mutualism concept, in order to gain proportional profit within the supply chain of coffee. Farmers got additional new technologies practiced on their lands to increase the coffee productivity and production, and improve quality of coffee beans through good manufacturing practices. Besides, they could also strengthen their capacities relating to aspects of management, organization, administration and finance. The achievement of this project (Nusa Tenggara Timur province) might be replicated in another province (Bali) which has big potential to develop coffee business. The aims of this study are: (i) to give an explanation about the inclusive business on coffee development in Bali; and (ii) to describe the efforts to develop the inclusive business on coffee production in Bali province, Indonesia.

\section{MATERIALS AND METHODS}

This study was purposively conducted in Kintamani (Bangli regency) and Pupuan (Tabanan regency) as the center production areas of coffee in Bali province, Indonesia. Arabica coffee area is in Kintamani, and Robusta coffee area is in Pupuan (see Figure 2). Materials needed in this study are equipment for interview and focus group discussion. 


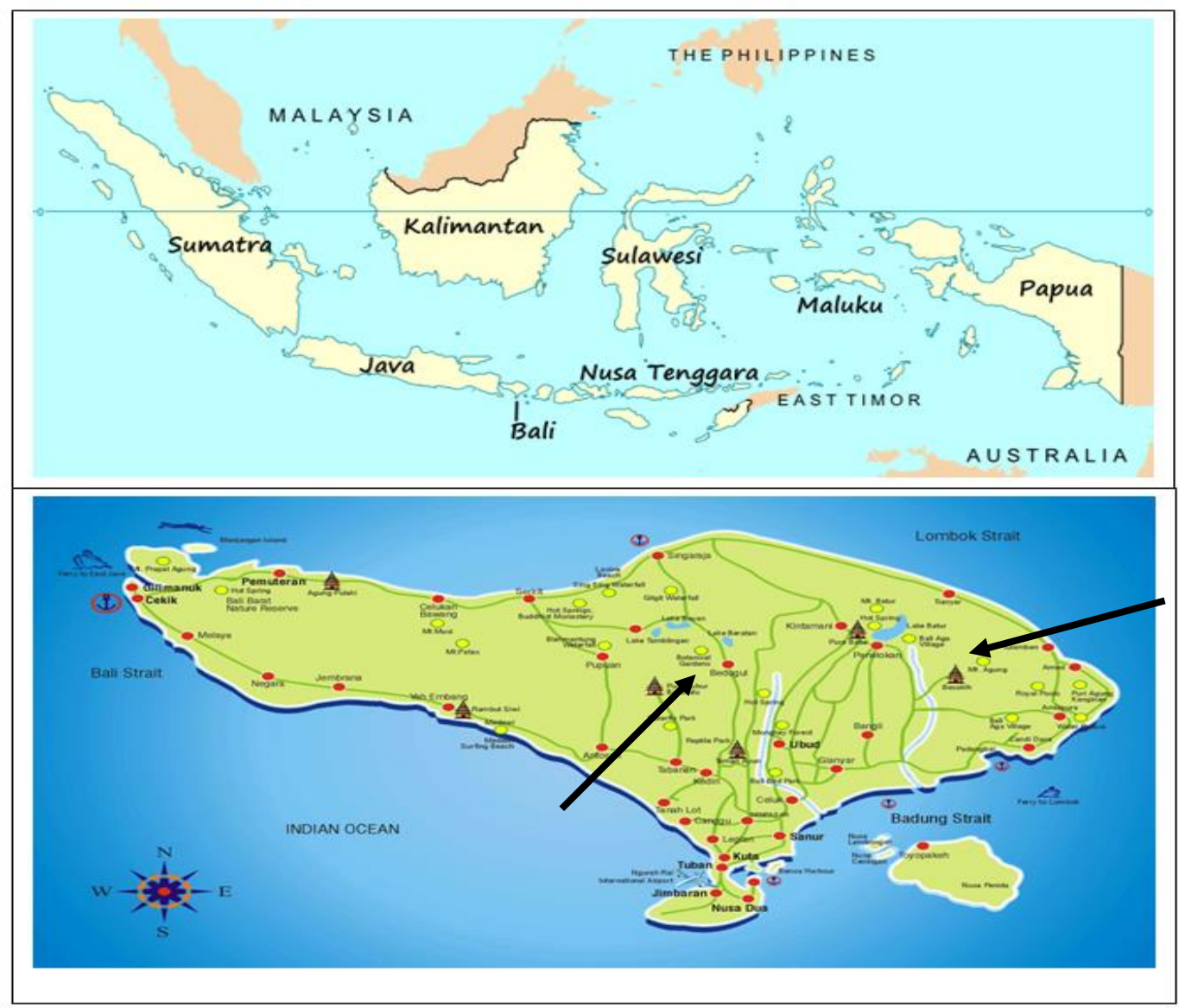

\section{Figure 2: Site map}

Primary and secondary data were collected in the study by using various techniques, such as survey, interview, direct observation and documentation. In order to have deep information, the technique of Focus Group Discussion (FGD) was also employed by inviting the key informants of farmers groups, market actors (local traders, exporters, officers of local governments, officers of local banks, and staff of research institution). In this study, data were analyzed by using descriptive method.

\section{RESULTS AND DISCUSSION}

\subsection{Potentials to the establishment of inclusive business}

Presently, the agricultural development has been implemented by employing the concept of agribusiness system. In this concept, it is very important to have strong and appropriate integration between the upstream and downstream sectors. In other words, the entire sub-systems of agribusiness must be interrelated among each other. The sub-systems of agribusiness are: (i) agroinputs and agricultural equipment sub-system; (ii) on-farm sub-system; (iii) processing subsystem; (iv) marketing sub-system; and (v) supporting sub-system. The integration among the subsystems indicates the inclusiveness of agricultural development. The other sectors (nonagricultural sector) are also involved in the development, such as industry, companies, irrigation, finance and others. 
Experience in coffee producing countries, the good cooperation among the market actors, such as the presence of companies, such as an exporter is one of the most important parts to buy farmers' products (Fadhil et al., 2018; Alejandra et al., 2012; Arifin, 2013). The specialty coffee has big potential to generate higher income to farmers and the exporters through the good processing and good quality standard product (Palmiro and Rossi, 2016). The inclusive business in this study is an approach to building a business that involves the participation and role of various market actors involved in business development. The actors that should be involved are farmers group, company, government, and other related actors. This business is based on a business model that has been jointly established by the actors (Sedana and Astawa, 2016). Every market actor in this inclusive business has a proportional role in the coffee market chain to get their own profits. Proper relationship established in the partnership is very important to build and maintain in order to ensure the sustainability of inclusive business (Aimin and Shunxi, 2011).

Learning from the experience of coffee development employing inclusive business in the Province of Nusa Tenggara Timur (Indonesia), it has been indicated that coffee farmers could have higher income gained from the coffee farming (Sedana and Astawa, 2016). The inclusive businesses implemented in the said site had been conducted through the project of AIP-PRISMA (AustraliaIndonesia Partnership-Promoting Rural Income through Support for Markets in Agriculture) since 2014 to 2016. The project covered two major activities, namely the Development of ICCRI's (Indonesian Coffee and Cocoa Research Institute) franchise and Development of Decentralized Processing Facilities for Specialty Coffee. In general, the objective of this project aims is to increase farmers' income through the improved on-farm technology and off-farm (postharvest) technology, and management system at the coffee farmers' group level. The improvement of these technologies is addressed to increase productivity of land and coffee trees, and quality of cherry and green bean coffee produced and processed by farmers.

Coffee development in Bali province might adapt the concept of inclusive business implemented in the Province of Nusa Tenggara Timur and other regions within some countries. The taste of coffee produced in Bali (Kintamani and Pupuan) has been well-known by the consumers in the world. Therefore, this should be maintained to supply coffee bean to the consumers, and give higher income to coffee farmers as producers. In the development of inclusive coffee business in Bali, such as in the Kintamani region (Arabica coffee center area, in Bangli regency), and Pupuan region (the center area for Robusta coffee, in Tabanan regency), the new coffee business approaches might be introduced and implemented; namely coffee inclusive business.

There are several potentials to develop inclusive business on coffee development in Bali province. These are as follows: (i) the existence of coffee farmers' groups; (ii) certificate of geographical indication; (iii) the existence coffee local traders and exporters; (iv) good physical infrastructure, such as transportation, communication; (v) support of local government; and (vi) support of financial services from the local bank.

The existence of coffee farmers' groups is one of the strengths to establish the inclusive business. Farmers must collect their product to make much more quantity. Good social interaction among the members of farmers' group could be a strong social capital for supporting the achievement of a group's objective (Sedana et al., 2014). This group needs to develop and strengthen its capacities in terms of management, organization, administration, business and financial aspects. Coffee produced by farmers in Bali is categorized as specialty coffee due to the specific taste. The central government has provided geographical indications for Kintamani coffee and Pupuan coffee. This means that Bali's coffee could be easier to promote and market as a specialty coffee (Quiñones et al., 2015).

Based on the data collected, the local traders and exporter within the sites of study are coming from the other regencies and provinces. The exporter of PT. Indokom Citra Persada coming from 
East Java province has also been operated in the sites. In addition, the other companies buying coffee in the sites are PT. Taman Delta (Central Java province) and PT. Sari Buana, as local buyers. They have already had a simple partnership in the process of marketing coffee. Their partnership, however, was not in the form of inclusive business. The actors of market did not work under the inter-dependency system, called cash and carry system. The farmers and farmers' groups sold their product to traders or exporters without any agreement as a real partnership. Therefore, the price of coffee is fully defined by the trader/exporter. This situation might be difficult to increase farmers' income gained from coffee farming. The market actors should be encouraged to have better partnership on coffee development under the inclusive business.

As a tourism destination, the two sites of study have good facilities of transportation from the city, harbor and airport. This condition is a big potential for the traders/exporters to have more efficient transportation cost (agro-inputs and products). Besides, communication system within the sites also is very good for farmers and traders and other market actors. They could easily access information in the relation to coffee development. These conditions should be a supporting subsystem of agribusiness to accelerate the economic activities among the actors of the market.

The local governments at the regency and provincial levels, especially the Plantation Services, have developed various programs to increase the productivity and quality of coffee at the farmers' level. These programs have been done partially by government, so the traders/exporters do not have direct responsibility to the programs of government. They worked without any agreement relating to the coffee development. They have their own businesses. It is therefore, needed to have the improved cooperation between the government institution and the private sector (trader/exporter), by establishing an inclusive business. They are expected to make agreements for the improved coffee development which addresses an increment in farmers' income.

At present, the local government bank has supported the farmers' groups to process their product in order to have added value. The government has facilitated the farmers' group which has a coffee processing unit to gain a loan from the local bank. Government encouraged farmers' groups to establish the coffee processing unit to produce better quality of coffee bean in order to have higher price from the trader/exporter. As a small scale enterprise, the farmers' groups could manage their administrative and finance aspects for coffee business development. This indicates that farmers' group has a potential to involve in the inclusive business. In terms of the inclusive business, the bank might provide much more loan to the farmers' groups (or coffee farmers cooperative) to enhance capital working for the production and post-production activities.

\subsection{Development of inclusive business}

Lessons learned from the other projects of inclusive business involving smallholder farmers, it has pointed out that the involvement of farmers in the said business could increase the added value of coffee produced by farmers. They could increase their productivity and quality of coffee after having a clear agreement with the trader/exporter and other market actors. The coffee farmers' groups in the sites of study have a big possibility to establish the inclusive business on coffee development due to the good economic environments.

Participatory approach should be implemented in the establishment of inclusive business. The independent agent, such as Non-Governmental Organization (NGO) might be involved to facilitate the process of inclusive business establishment through the informal and formal meetings among the market actors. The NGO should make identification and inventory about the actors of market, which would be involved in the inclusive business. At least, the actors are: (i) coffee farmers' group/cooperative, (2) Exporter of coffee (PT. Indokom Citra Persada or PT. Taman Delta), (3) regional government bank (Bank of Regional Development), (4) Indonesian Coffee and Cocoa Research Institution (ICCRI) as a research institute, and (5) NGO as independent agent. 
Learning from the inclusive business development in Flores, the participation of all market actors based on the established business model has been initiated. For example, the coffee exporters (PT. Indokom Citra Persada) had been involved from the beginning of the established business plan. The exporter had been involved to obtain an overview and information about warehouse capacity, purchase estimates, price estimates and exports and other important information. In this project, VECO-Indonesia has been appointed as an International Non-Governmental Organization (INGO) to be a co-facilitator.

The inclusive business under the project implemented in the East Manggarai (Flores), involved several actors of market to implement the inclusive business. These actors are (i) coffee farmer cooperatives, (2) Exporter of coffee (PT. Indokom Citra Persada), (3) regional government bank (Bank of Nusa Tenggara Timur), (4) Indonesian Coffee and Cocoa Research Institution (ICCRI) as a research institute, and (5) an international NGO (VECO-Indonesia).

Based on the experience of Flores, it is very important to adopt the business model established to develop an inclusive business in Bali. There is relatively similar characteristic of market actors in Flores and Bali. Therefore, the business model established should include the farmers, buyers, banks, government, research institution, and independent actors. The alternative business model is shown in the Figure 3.

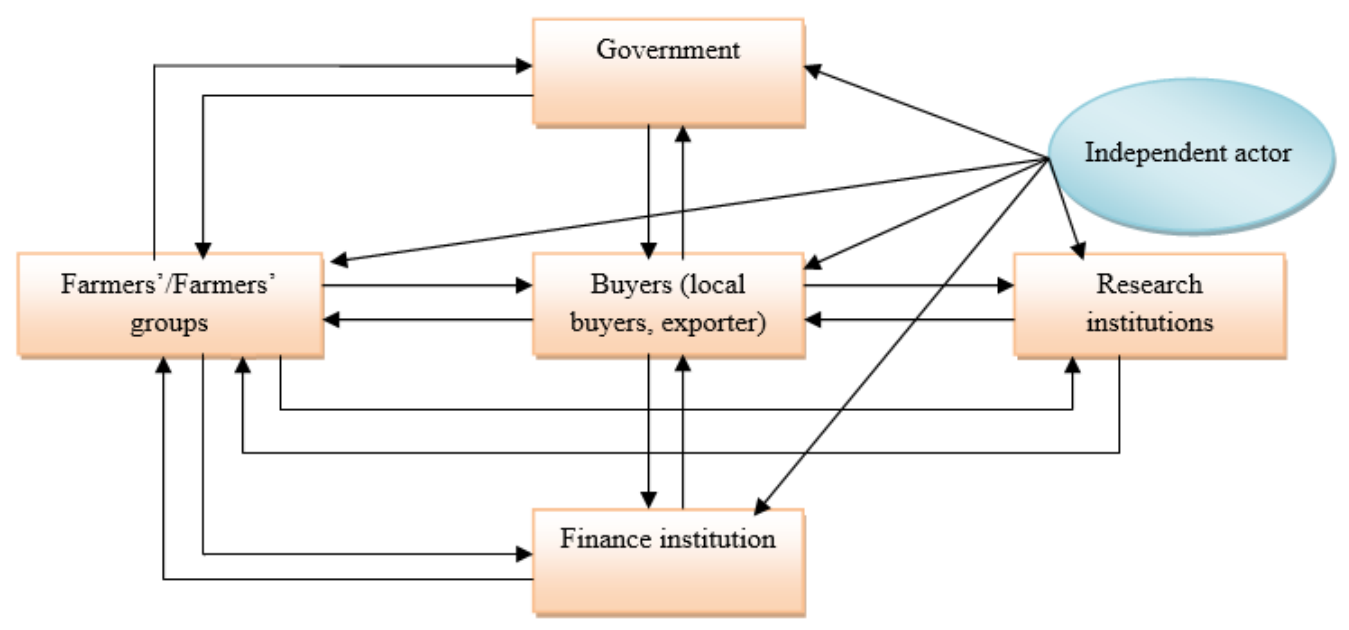

Figure 3: Business model in the inclusive business on coffee development

At the farmer or farmers' group level, the development of coffee in Bali in general should have the aim of increasing the income of coffee farmers through various activities. These activities are as follows: (i) increasing productivity by the application of the good agricultural practices; (ii) improving quality of product through the appropriate post-harvest techniques, such as good Postharvest practices, and good manufacturing practices; (iii) providing of processing facilities such as drying equipment and storage to support producing the good quality of coffee; (iv) increasing capacity and techniques for quality coffee; (v) improving the capacity of group managers and or farmer cooperatives in terms of the aspects of management, administration and leadership; (vi) establishing good mutualism of partnerships with buyers, or exporter; and (vii) creating added value of products.

In Figure 3, it can be seen that there is a reciprocal relationship between several market actors in the business model. In the relationship between farmer cooperative and coffee exporter/buyer, for instance, there will be the exchange of things based on their agreement. Farmer cooperative will provide coffee beans in line with the quantity and quality as demanded by the buyers or exporters. 
This quality must be in accordance with international standards of coffee beans. Meanwhile, the exporter/buyer will provide expert inputs, extension, training or technical assistance to farmer cooperatives in the connection with the good techniques or methods of processing coffee, and provide payments to the coffee bought at prices agreed upon previously. This reciprocal relationship shows the interdependence between the two actors in the process of developing the coffee inclusive business, so there is no relationship based on the charity.

Increasing the productivity of coffee at the farmers' cooperative level might be done through the establishment of partnership between the cooperative and the research institution. Based on the study, one of the research institutions having good experiences in coffee development is the Indonesian Coffee and Cocoa Research Institution, in Jember, or the local university in Bali. This institution has a basket of technologies of coffee production. The research institution has function to provide expert technologies or practices on the coffee production. This includes, selecting coffee varieties, grafting, fertilizing, pruning, pest and disease control/management and others. Farmers should be given agricultural extension and training in order that they have better farming, better business and better living. The behavior (knowledge, attitude and skill) of farmers toward good agricultural practices should be an important thing to increase the productivity of trees and land. The agent of research institution might employ the participatory approach in the implementation of extension and training.

Similarly, the reciprocal relationship is also shown between the farmer cooperative and the local bank within the research sites. The local bank, which has strong commitment to support farmers' groups, is The Bali Development Bank. This bank has branches in the districts scattered within Bali province. The Bank should be encouraged to provide working capital loans to coffee farmer cooperatives in order to have increased capacity to buy more coffee (red cherries) from farmers. By this loan, the cooperative might also be expected to have more quantity and better quality of coffee bean processed in accordance with the standard operational procedures given and trained by the exporter. On the other hand, the farmer cooperative should provide guaranty to the bank regarding the feasibility of business by showing the prospective business plan. Besides, the cooperative should also have a professional and accountable business organization in managing finances, including loans from the bank. In this partnership, the bank will receive interest payments from the loans that would be given to farmer cooperatives. The bank might have a function to train officials or management board of cooperatives in order that they have a better capacity in the management of the cooperatives. In more detail, the obligations and rights of each party can be determined through an agreement between them.

In the research sites, the establishment of inclusive business on coffee production needs a participatory approach. The role of an independent party or Non-Governmental Organization (NGO) might be involved in this activity. Firstly, the NGO and the entire market actors should have a small discussion to have similar understanding about the coffee inclusive business. They are initiated to prepare the basic information needed in the plan of inclusive business. Each market actor gives information about the profile, the needs for production, capabilities and other information. Furthermore, the NGO might facilitate to have Focus Group Discussion (FGD) concerning the objective of inclusive business, involvement of market actors, benefit or profit, problems, alternative solutions and others. The main objective of FGD is to define the business model that would be a guide for the implementation of inclusive business on coffee production.

Based on the experiences in other parts of Indonesia, the development of an inclusive coffee business in Bali, therefore, also needs to adopt those experiences, such as in Ngada, Manggarai, and East Java. The market actors should make an agreement or memorandum of understanding about the implementation of inclusive business. The agreement made among the market actors must have the principle of mutual benefit. The scope of the agreement includes: 
1. Improved technology (GAP) and increased productivity and production;

2. Improving the quality of coffee beans, namely as superior specialty coffee based on the standards of domestic and international markets;

3. Providing guarantees of access to information and markets (types, quality and prices) at the domestic and international levels;

4. Providing financial services to increase business capital and investment for market actors to realize technological improvements, increase productivity and quality of coffee produced by farmers and other market actors; and

5. Enhancing and strengthening the capacity of farmers and farmer organizations (management, administration, finance) to realize an independent and professional entrepreneurial spirit and business organization.

It is suggested that the government at the provincial level and regency level should be included in the event of signing an agreement. They would have important roles in supporting the inclusive business on coffee production, such as creating development programs for achieving the objective of inclusive business. Aside from this, government is expected to issue the policies supporting the inclusive business on coffee development. At least, the government policies will be able to create an advantageous climate for all market actors in developing an inclusive coffee business. It is also hoped that the government can monitor and evaluate the implementation of this inclusive business, whether it is in accordance with the established business model, in order to increase coffee farmers' income gained from their coffee farming, and encourage economic growth in the region.

Market actors who are directly involved in this inclusive business are the Coffee Farmers Cooperatives in the development area, such as farmer cooperatives in Kintamani or in other coffee centers. This farmer cooperative acts as a representation of the interests of coffee farmers, which starts from the process of preparing production, production to post-harvest. Farmers should have better knowledge, attitude and skill on the coffee practices (Megerssa et al., 2012). Farmer cooperatives with their units formed (coffee business enterprises, such as the processing unit) can have several roles concerning the efforts to increase productivity and quality of coffee. These roles are as follows:

1. To strengthen the capacity of members (farmers) to have knowledge, attitudes and skills regarding good agricultural practices on coffee plantation to produce higher productivity with good quality of cherry.

2. To encourage and increase the capacity of farmers and cooperative managers related to postharvest techniques or good post-harvest practices and good manufacturing practices (picking appropriate coffee fruit, such as red, processing in accordance with the standard operation procedure that has been given is good for processing wet or dry, and marketing).

3. Increasing the understanding and mastery of the skills of farmers and managers of cooperatives in relation to socioeconomic aspects, such as entrepreneurial spirit, management, organization and finance and partnerships to support coffee farmer cooperative programs.

The Bank as a market actor has functions and obligations relating to financial provision. Some functions and obligations of the bank are as follows:

1. Providing financial services to coffee farmers' cooperatives with easy mechanism and low interest;

2. Providing additional services, namely strengthening the capacity of farmer cooperative managers in financial management in a professional and accountable manner, so that mutual trust can be realized between the farmers and the management, and among the management of the cooperative with the bank, including with other market actors. The bank should provide specific training for the management board of farmer cooperatives to ensure the realization of professional and accountable financial management. 
3. Being a coffee management partner or exporter, especially in the aspect of capital with a financing scheme that is in accordance with bank policies and cooperation with these companies.

Coffee companies (exporter or buyer) as important market actors should have roles in buying the products produced by farmers or farmers' cooperatives. In the inclusive business, the functions and obligations of the coffee companies are as follows:

1. Providing guarantees for market access to coffee produced by farmers and processed by processing units under the management of farmer cooperatives;

2. Provide training to managers of cooperatives and coffee processing units about good processing techniques (if wet or dry) to produce coffee quality that is in line with market demand home and abroad;

3. Provide technical assistance to the manager of the results processing unit and farmer cooperatives in the aspect of processing coffee in accordance with the standard operational procedure;

4. Monitor and evaluate the coffee processing process carried out by the coffee processing unit and farmer cooperatives, to ensure that the amount of coffee produced and the quality is as requested by the market;

5. Providing reasonable prices at the cooperative level through negotiating prices together with cooperatives and the government.

The research institute or the ICCRI (in Jember) also has an important role in the development of coffee-inclusive business. The functions that might be played by universities or research institutions are:

1. Providing information about good coffee cultivation technology and good coffee processing techniques;

2. Providing extension and training to cadres of coffee farmers (who are appointed or selected by the farmers' cooperative) to be able to carry out and develop coffee cultivation technology for other farmers;

3. Providing technical assistance in making nurseries at the farm level, including the selection of superior local clones; and

4. Carrying out technical monitoring and evaluation of the development of coffee cultivation at the farm level.

Whereas other parties that are not less important are the existence of independent institutions such as the Non-governmental Organization (NGO), which has a function to facilitate farmers, product processing units, cooperatives, government, coffee entrepreneurs, banks and universities or research institutions. This NGO can also function to facilitate work to strengthen the capacity of farmers' cooperatives as a business organization in the development of independent and professional coffee inclusive businesses. Strengthening farmer cooperatives is directed towards becoming a business organization that produces high competitive coffee because of its good quality at the international level. Some activities that can be carried out by these NGOs are empowerment through activities to strengthen the capacity of farmers and cooperative managers, such as organizing field school activities, internships, regular assistance, comparative study visits, and exhibitions, as well as other business activities.

Inclusive business which is conducted under the business model by the market actors might ensure them to obtain proportional economic incentive. This incentive could be motivation of the actors to have better mutualism partnership on the business. Therefore, this could make the sustainable inclusive business done by the market actors. 


\section{CONCLUSION}

Inclusive business implemented in Flores is suitable to adopt in Bali province, due to the similar situation between the two regions. In order to solve the main problems in coffee development, the inclusive business under the business model should be introduced. Development of inclusive business on coffee production should involve the market actors on coffee development, such as coffee farmers/farmers' groups/cooperatives, buyers/exporters, government, finance institution, research institution, and NGO as the independent actor. The market actors should play a role based on the agreement which has been established. They should have mutualism partnership, not based on the charity scheme. They are expected to obtain the proportional economic incentives for themselves under the inclusive business. Therefore, this could ensure to achieve the sustainable inclusive business on coffee development.

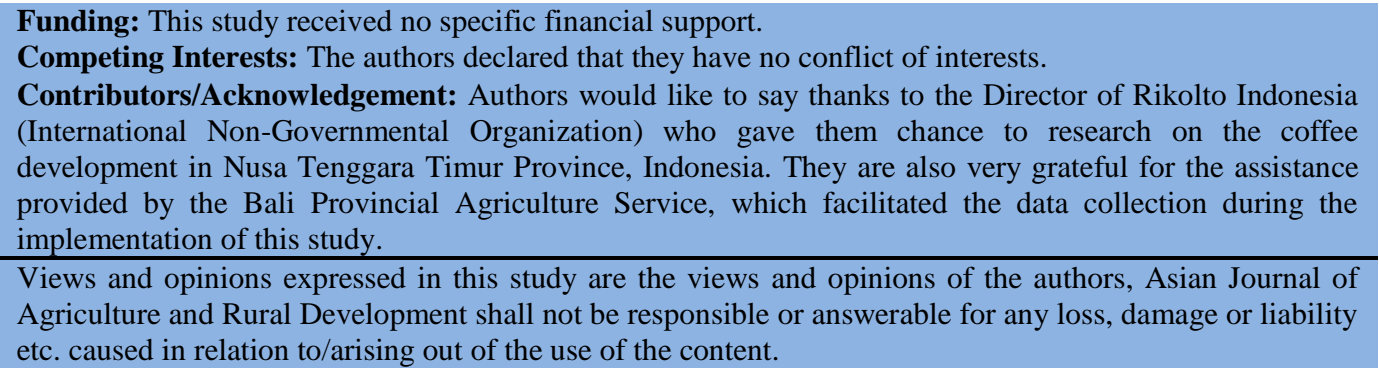

\section{References}

Aimin, W., \& Shunxi, L. (2011). A model of value chain management based on customer relationship management. Journal on Innovation and Sustainability, 2(3), 17-21. doi.org/10.24212/2179-3565.2011v2i3p17-21.

Aknesia, V., Daryanto, A., \& Kirbrandoko, K. (2015). Business development strategy for specialty coffee. Indonesian Journal of Business and Entrepreneurship, 1(1), 12-22. doi.org/10.17358/ijbe.1.1.12.

Alejandra, M., Perez, G., \& Viana, S. (2012). Cooperation in coffee markets: the case of Vietnam and Colombia. Journal of Agribusiness in Developing and Emerging Economies, 2(1), $57-$ 67. doi.org/10.1108/20440831211219237.

Arifin, B. (2013). On the competitiveness and sustainability of the Indonesian agricultural export commodities. ASEAN Journal of Economics, Management and Accounting, 1(1), 81-100.

Ayelign, A., \& Sabally, K. (2013). Determination of chlorogenic acids (CGA) in Coffee Beans Using HPLC. American Journal of Research Communication, 1(2), 78-91.

Belachew, K., Teferi, D., \& Gidisa, G. (2015). Screening of some coffee arabica genotypes against coffee wilt diseases (Gibberella Xylarioides Heim and Saccus) At Jimma, Southwest Ethiopia. International Journal of Sustainable Agricultural Research, 2(3), 66-76. doi.org/10.18488/journal.70/2015.2.3/70.3.66.76.

Dowdall, C. (2012). Small farmer market knowledge and specialty coffee commodity chains in Western Highlands Guatemala [disertation]. Florida: Florida International University.

Fadhil, R., Maarif, M. S., Bantacut, T., \& Hermawan, A. (2018). Situational analysis and intervention strategy for Gayo coffee agroindustry institution in Indonesia. Journal of Food, Agriculture \& Environment, 16(1), 31-40.

Gathura, M. N. (2013). Factors affecting small-scale coffee production in Githunguri district, Kenya. International Journal of Academic Research in Business and Social Sciences 3(9), 132-149. doi.org/10.6007/ijarbss/v3-i9/195.

Kilian, B., Jones, C., Prastt, L., \& Villalobos, A. (2006). Is sustainable agriculture a viable strategy to improve farm income in central America? a case study on coffee. Journal of Business Reseach, 19(3), 322-330. doi.org/10.1016/j.jbusres.2005.09.015. 
Mapiemfu-Lamaré, D., Ngome, A. F., Eyenga, E. F., Mbassi, J. E. G., \& Suh, C. (2017). Harvesting date influences cassava (Manihot Esculenta Crantz) yield and quality of basedproducts. Current Research in Agricultural Sciences, 4(3), 75-83. doi.org/10.18488/journal.68.2017.43.75.83.

Megerssa, B., Michael, G., \& Teshome, D. (2012). Knowledge and attitude of small holder coffee producing farmers to coffee quality: the case of Oromiya and South Nations Nationalities and peoples regional states, Ethiopia. Journal Application Science Technology, 3(2), 31-44.

Minh, H. T., Trang, D. T. N., \& Chen, J. C. (2016). Input factors to sustainable development of coffee production in the Dak Lak province. Scientific Research, 3(12), 1-10. doi.org/10.4236/oalib.1103187.

Ministry of Agriculture (2017). Report on coffee production statistics. Jarkarta.

Mutandwa, E., Nathan, T. K., Emmanuel, R., Theophile, K., Patrice, M., Ignatius, G., \& Richard, F. (2009). Analysis of coffee export marketing in Rwanda: application of the Boston consulting group matrix. African Journal of Business Management, 2(4), 210219.

Palmiro, P., \& Rossi, F. (2016). Challenges in specialty coffee processing and quality assurance. Challenges, 7(2), 1-22. doi.org/10.3390/challe7020019.

Quiñones-Ruiz, X. F., Penker, M., Vogl, C. R., Samper-Gartner, L. F. (2015). Can origin labels reshape relationships along international supply chains? The case of Cafe de Colombia. International Journal of the Commons, 9(1), 416-439. doi.org/10.18352/ijc.529.

Sedana, G. I., Ambarawati, G. A. A., \& Windia, W. (2014). Strengthening Social capital for agricultural development: lessons from Guama, Bali, Indonesia. Asian Journal of Agriculture and Development, 11(2), 39-50.

Sedana, G., \& Astawa, N. D. (2016). Panca datu partnership in support of inclusive business for coffee development: the case of ngada district, province of Nusa Tenggara Timur, Indonesia. Asian Journal of Agriculture and Development, 13(2), 75-98.

Supriadi, H., \& Pranowo, D. (2015). Prospek pengembangan agroforestri berbasis kopi di Indonesia (Prospects of agro-forestry on coffee trees in Indonesia). Perspektif, 14(2), 135 150. doi.org/10.21082/p.v14n2.2015.135-150. 